Kral, P., Musa, H., Lazaroiu, G., Misankova, M., \& Vrbka, J. (2018).

Comprehensive assessment of the selected indicators of financial analysis in the context of failing companies. Journal of International Studies, 11(4), 282-294.

doi:10.14254/2071-8330.2018/11-4/20

\title{
Comprehensive assessment of the selected indicators of financial analysis in the context of failing companies
}

\author{
Pavol Kral \\ Department of Economics, University of Zilina, \\ Slovakia \\ pavol.kral@,fpedas.uniza.sk
}

\section{Hussam Musa}

Department of Finance and Accounting, Matej Bel University in

Banska Bystrica, Slovakia

bussam.musa@umb.sk.

\section{George Lazaroiu}

Faculty of Socio-Human Sciences, Spiru Haret University,

Romania

phd_lazaroin@yahoo.com

\section{Maria Misankova}

Department of Economics, University of Zilina,

Slovakia

maria.misankova@fpedas.uniza.sk

\section{Jaromir Vrbka}

The Institute of Technology and Business in Ceske Budejovice, School of Expertness and V aluation, Czech Republic

vrbka@mail.vstecb.cr.

Abstract. Financial ratios can be considered a crucial determinant of reliability for the bankruptcy prediction models. Therefore, it is necessary to be vigilant during the preparation of bankruptcy prediction models so that to include those ratios, which ensure the highest degree of predictive power. The aim of this paper is to define the so-called etalon unsuccessful business that can serve as a standard comparative basis for other unsuccessful companies operating in Slovak Republic. Own quantification of the selected ratios was created on the database of the published financial statements of several thousand businesses operating in Slovak Republic between 2014 and 2015. This database has undergone extensive filtration of extreme data for maximal objectification of the results. Universal criterion for inclusion of a enterprise into the category of

Received:

June, 2018

1st Revision:

October, 2018

Accepted:

November, 2018 .

.


unsuccessful enterprises through the values of the three ratios (R1, L3, Z4) have been created. This criterion was named as unsuccessfulness indicators while respecting the applicable legal standards of Slovak Republic governing the conditions of unsuccessfulness.

Keywords: failing companies, bankruptcy prediction, financial ratios.

JEL Classification: C53, G33

\section{INTRODUCTION}

The decisive qualitative attribute of prediction models is their ability to classify entities with sufficient reliability into the category of prosperous (solvent) or non-prosperous (insolvent) entities. The level of predictive ability varies upon the existing models, logically, the value declines with the period of time for which the prediction is executed. Input data for models are data taken from entity's financial statement.

There are various prediction models, which differ in approaches and methods applied for their compilation, demand for input data, number of variables, form of result's interpretation etc. The existence of large number of models is caused by the fact that there is no universal application in various sectors and economic conditions. It is understandable that creators of prediction models strive to create a model that would be able to provide a required value of prediction capability within the longest possible period of time, however, it is very difficult to do in the environment of ever-changing market conditions. By studying and analysing the information sources behind bankruptcy prediction models, three groups integrating the models based on the approaches used for their construction were established: 1. Statistical prediction models, 2. Artificially intelligent experts systems models (AIES models), 3. Theoretical models. On this basis, and also on the basis of assessment of the predictive power of hundreds of applied bankruptcy model, we can conclude that there is no method for comprehensive evaluation of company's performance that would be able to predict its development with full success. The aim of every creator of a prediction model is, of course, to ensure the highest value of predictive power, which is an essential indicator of its quality.

\section{LITERATURE REVIEW}

A simple literature search can find many of publications on this topic. Ratio indicators such as liquidity, profitability, capital adequacy and so on, depending on the needs of the specific analysis, are treated as standard instruments for measuring of the company performance. Use of financial ratios to bankruptcy prediction is not new (Mihalovič, 2016; Balcerzak et al, 2018; Gavurova et al, 2017). Horrigan (1965) claimed that the development of financial ratios ought to be a unique product of the evolution of accounting procedures and practices in the U.S., also stating that the origin of financial ratios and their initial use goes back to the late 19th century. There are many studies focused on analyzing and potentially predicting bankruptcy as a means to identify characteristics (in term of financial ratios) of good or badperforming firms (Kumar \& Ravi, 2007). Cinca et al. (2005) proved that the size of the company and the state where the company is located impact the financial ratio structure. The quality of the information provided by financial ratios is very important in bankruptcy prediction because it impacts on the accuracy of the bankruptcy prediction ((Maricica \& Georgeta, 2012).

Evaluating firm performance using financial ratios has been a traditional yet powerful tool for decision-makers, including business analysts, creditors, investors, and financial managers. Rather than 
employing the total amounts observed on financial statements, these analyses were conducted using a number of financial ratios to obtain meaningful results. Ratio analysis can help stakeholders analyze the financial health of a company. Using these financial ratios, comparisons can be made across companies within an industry, between industries, or within a firm itself. Such a tool can also be used to compare the relative performance of different size companies (Delen et al, 2013). Companies do not only focus on financial aspects, but also have to focus on development as well - preparedness, ability to learn, innovation, and the use of information. Moreover, they must continually improve relationships with customers and suppliers. Companies are largely managed through financial indicators, but the current trend is showing the increasing importance of non-financial measurers, too (Dobrovic et al, 2018).

Bankruptcy prediction models, either classic (classical univariate analysis of bankruptcy risk is based on financial ratios and consists of company's performance and risk analysis at the operating and the financial levels of activity) or modern (discriminant analysis, logistic regression, probit, linear probability model, neural networks etc.), are essentially based on financial ratios (Maricica \& Georgeta 2012). Techniques used for the estimation of credit risk have changed in recent years, so this has resulted in the expansion of new models for the estimation and evaluation of the likelihood of bankruptcy of individuals or companies and new parameters identifying possible losses. These parameters include Loss Given Default and express the proportion of an exposure which will not be recovered after defaults of individuals or companies (Lando, 2004). There are many dimensions upon which to measure the performance of a credit scoring system, but the most relevant way to compare models with different sample sets is by measuring the models' ordinal ability to differentiate between companies that are most likely to go bankrupt from those that are least likely to go bankrupt (Bemmann, 2005). Mears (1966) says that financial ratios do not possess the ability to predict bankruptcy in an absolute manner and that their utility is given by the power to signal about the company's financial health problem and their potential causes. Libby (1975) believes that a narrow set of financial ratios allowed a high degree of accuracy in bankruptcy prediction. Financial ratios (profitability, solvency, cash flow ratios, capital structure ratios and others) are the most important factors affecting bankruptcy prediction, are used to develop prediction models. On the other hand, though, several recent studies have found that corporate governance indicators (five categories: board structure, ownership structure, cash flow rights, key person retained and others) also play a key role in predicting bankruptcy (Bredat, 2014; Liang, 2013). The combination of financial ratios and corporate governance indicators can improve the models performance when compared with the model based on financial ratios alone. Specifically, stepwise discriminant analysis (SDA + support vector machine (SVM) performs the best. The most important features for effective bankruptcy prediction are the financial ratios categories of solvency and profitability and the corporate governance indicators categories of board structure and ownership structure. Without using these features, the prediction model cannot perform significantly better than the one based on financial ratios alone. However, the usefulness of using corporate governance indicators is market dependent (Liang, 2016).

Corporate failure often occurs when a firm experiences serious losses and/or becomes insolvent with liabilities that are disproportionate to its assets (Mousavi, 2015). Corporate failure can exist in various types and dimensions, and has different effects on stakeholders according to magnitude of the failure and its type. The rise of corporate failure in different types brought about the use of different definitions and different concepts connoting failure. Over the past 35 years, the topic of "business failure prediction" has developed to a major research domain in corporate finance. Many academic studies have been dedicated to the search for the best corporate failure prediction, based on publicly available data and statistical techniques (Kliestik et al, 2018).

Bankruptcy prediction is a very important task for companies and many related financial institutions. In general, the aim is to predict the likelihood that a firm may go bankrupt. Financial institutions are in 
need of effective prediction models in order to make appropriate lending decisions (Liang et al, 2016).With the increasing number of quantitative bankruptcy models available, one of the challenging issues faced by both academics and professionals is how to evaluate these competing models and select the best one(s) (Mousavi, 2015). Most models that are designed to forecast corporate bankruptcy are usually built using a limited number of financial ratios that are measured once (Balcaen \& Ooghe, 2006). Svabova, L. \& Durica, M. (2016), using tools of correlation analysis, found out that some of proportional financial characteristics of companies they considered have a significant linear relationship between them called multicollinearity. This relationship is often not very strong, but tests confirmed that it is significant, therefore, it cannot be considered accidental. Financial ratios that have shown significant statistical relationship were those using the same indicator in the denominator of the ratio for its calculation. This should be taken into account in designing prediction models of company bankruptcies, when authors think of those predictors included in the model in order to guarantee the independence of explanatory variables. There are researches that evaluate impact of the ratio indicators on the brand value. Janoskova, K. \& Kliestikova, J. (2018) conclude in their research that a randomly selected financial indicators show mostly positive linear correlation to the brand value. According to Rowland et al. (2016) the most frequently occurring defects of bankruptcy prediction models are: assumption of bipolar relationship of variables, methodology for the selection of data set of sample enterprises, assumption of instability of data, selection of independent variables, the use of annual financial statements, time dimension.

\section{METHODOLOGY}

Selected financial ratios of financial analysis of an unsuccessful companies based on enterprises database we processed were quantified. This database was compiled from electronic publication of financial statements for 2014 and 2015. It is necessary to emphasize that from the point of time period, it is a considerably limited selection, determined by availability of source data, i.e. electronic publication of financial statements. Therefore, it is not possible to capture the long-term trend on reliable basis, however, we possess an extensive basic file of unsuccessful enterprises for two consecutive years, i.e. meeting the prerequisite of an extensive statistic data determination. The year 2014 was selected as a starting point for financial ratio indicator quantification of unsuccessful enterprises since in 2014, there was a change to electronic publishing of financial statements. Therefore, it is not possible to include the previous years into the model as it would cause distortion of results. The ambition is to further expand the financial statement database by further years as well to provide a more complex and reliable overview to unsuccessful etalon company of the national economy of Slovakia.

State of an enterprise and prediction of its bankruptcy may be, apart from financial indicators, also reflected by other indicators of quantitative nature. In such case, the effort is to focus to selected financial analysis indicators, often used in bankruptcy prediction models. The three ratio financial indicators are classified as unsuccessfulness indicators, their values are decisive for categorizing the enterprise as successful or unsuccessful. They are the subject of the utmost attention in this paper.

The primary database has undergone extensive treatment, which was required by the character of the data. In many cases, the financial statements were incomplete or contained logical errors that have been verified on the basis of the validity rules of the balance-sheet. Only after this selection were the chosen ratios quantified. If these indicators could not be quantified or the value of the indicator was incorrect, we eliminated the company from the master database. After verification of the conditions of unsuccessfulness the company was included into a prosperous or unsuccessful category. In order to ensure the comparison comparability of enterprises in the years 2014 and 2015, the database contains only those companies that 
meet the correction conditions in both years. These corrections and conditions have filtered out 62,533 businesses, representing 73.2\% enterprises of the original master database for 2015 and $62.4 \%$ in 2014 .

62,533 enterprises were filtered based on meeting the conditions for unsuccessfulness ( 3 conditions that must be fulfilled at the same time) and got 9,985 enterprises in 2014 (15.96\% of the enterprises from the adapted database) and total of 9,552 enterprises for 2015 (15.27\% of the enterprises from the adapted database). The annual difference of the number of unsuccessful enterprises is almost negligible. Given that some quantified ratios of the unsuccessful enterprises possess extreme values, another database cleanup was stepped. Enterprises that showed extreme values in at least one of the reatios were excluded from the database. The threshold for extreme values of the indicators was set based on the frequency of their occurrence. For example, in case of the indicator R1 - net return on assets, a value of -10 was considered as a threshold value. So the database includes enterprises, for which the value of R1 is in interval $(-10 ; 0)$. The bottom limit value of the interval (-10) was set theoretically, by manual searching the database with goal to eliminate extreme values of R1 represented in small numbers. From the value of R1 $=-10$, the difference of neighbouring values in case of ascending enterprise database according to R1 increases evenly. Just the first 10 enterprises, in the ascending order, reached extreme values of R1 from within the interval $(-60014 ;-358)$. The bottom limit value of $\mathrm{R} 1=0$ interval is directly set by condition of unsuccsessfulness of enterprise (the profit after tax is a negative value). For indicator L3 - total liquidity there is a limited interval of values $(0 ; 1)$. The top limit value of $\mathrm{L} 3$ indicator interval is given by the defined unsuccessfulness condition: total liquidity L3 $<1$. In case the L3 $\geq 1$, the enterprise is already classiffed as successful. By using the indicator Z4 - financial independence indicator, there was an acceptability interval set, within the range of values $(-0.9 ; 0.04)$. The bottom limit of interval was determined similarly to the R1 indicator. The top limit value (0.04) is a defined condition of unsuccessfulness, in accordance with legal regulations valid in Slovakia.

This selection should ensure so that the extreme values of indicator do not distort later quantified descriptive statistical characteristics of the file. The results of the elimination are the final databases for the year 2014 with the total number of 8,708 unsuccessful enterprises and for 2015 with the total number of 8,137 unsuccessful enterprises. Size of the company, its trade focus, geographic scope or subject of business was not taken into account when creating the database. The sample of the examined financial statements is abundant enough to enable us to generalize the gained results. These databases were used for quantification of selected descriptive statistical characteristics, on which following parts of the paper are focused.

\section{EMPIRICAL RESULTS AND DISCUSSION}

\subsection{Definition of unsuccessfulness conditions}

According to the applicable legal regulations of the Slovak Republic (law no. 513/1991 coll. Commercial Code, as amended) a company is in crisis if it is in a recession or in a risk of recession. By law no. $7 / 2005$ coll. Of bankruptcy and restructuring as amended, a company is in recession if it in overdebt (an enterprise which is required to keep accounts according to law no. 431/2002 coll. On Accounting as amended, has more than one creditor and the value of its liabilities exceeds the value of its assets, i.e. has negative equity) or is insolvent (a company that is not able to pay at least two 30 days overdue financial obligations to more than one creditor).

It is not possible to determine from the financial statements of the enterprise whether the insolvency of the company is bound to at least two financial obligations after the 30-day maturity period, while tied to more than one creditor. This criterion has been replaced by an indicator L3 and setting the limit value level at $\mathrm{L} 3<1$. 
13 ratios of the financial analysis (profitability, activity, liquidity, indebtedness and capital structure) of businesses in category of unsuccessful enterprises were quantified:
R1 - return on assets (net)
$\mathrm{R} 3$ - return on corporate earnings (net)
L1 - immediate liquidity
L2 - current liquidity
L3 - total liquidity
L4 - relative indicator of net working capital
$Z 1$ - indicator of coverage of assets
Z2 - indicator of total debt ratio
$Z 3$ - indicator of common debt
$Z 4$ - indicator of financial independence.

$\mathrm{R} 2$ - return on total capital (gross - before interest and taxes)

$A 1$ - indicator of commitment of assets (in total revenues)

$A 2$ - indicator of commitment of current assets (in total revenues and net of accruals of assets)

Table 1

Ratio indicators

\begin{tabular}{|c|c|c|}
\hline Indicator label & $\begin{array}{l}\text { The calculation procedure (input } \\
\text { variables) }\end{array}$ & Interpretation \\
\hline $\mathbf{R} 1$ & (profit after tax) $\div$ (liabilities) & $\begin{array}{l}\text { how many euros of profit (net profit) accounts for } 1 \text { euro } \\
\text { in capital }\end{array}$ \\
\hline $\mathbf{R} 2$ & $\begin{array}{l}\text { (profit before tax }+ \text { interest expense) } \div \\
\text { (liabilities) }\end{array}$ & $\begin{array}{l}\text { how many euros of profit before tax and interest accounts } \\
\text { for } 1 \text { euro in capital }\end{array}$ \\
\hline $\mathbf{R 3}$ & (profit after tax) $\div$ (revenues) & $\begin{array}{l}\text { how many euros of profit (net profit) accounts for } 1 \text { euro } \\
\text { of the revenues of the company achieved from economic } \\
\text { and financial activity }\end{array}$ \\
\hline L1 & $\begin{array}{l}\text { (short-term financial assets }+ \text { financial } \\
\text { accounts }) \div \text { (short-term foreign capital) }\end{array}$ & $\begin{array}{l}\text { highlights the immediate ability of the company to settle all } \\
\text { current liabilities through immediate liquidity and } \\
\text { equivalents without need to monetize other items of } \\
\text { current assets or long-term assets }\end{array}$ \\
\hline $\mathbf{L 2}$ & $\begin{array}{c}\text { (current financial assets }+ \text { financial accounts } \\
+ \text { short-term receivables }) \div(\text { short-term } \\
\text { foreign capital })\end{array}$ & $\begin{array}{l}\text { highlights the immediate ability of the company to settle all } \\
\text { current liabilities through immediate liquidity and } \\
\text { equivalents and monetization of short-term receivables, } \\
\text { without need to monetize inventory, or other items of } \\
\text { long-term assets }\end{array}$ \\
\hline L3 & $\begin{array}{c}\text { (short-term assets }) \div(\text { short-term foreign } \\
\text { capital })\end{array}$ & $\begin{array}{l}\text { highlights the immediate ability of the company to settle all } \\
\text { current liabilities through immediate liquidity and } \\
\text { equivalents and monetization of short-term receivables and } \\
\text { inventory }\end{array}$ \\
\hline L4 & (net working capital) $\div$ (assets) & $\begin{array}{l}\text { expresses the extent to which is net working capital } \\
\text { involved in covering assets }\end{array}$ \\
\hline $\mathrm{Z} 1$ & (Profit from previous years) $\div$ (assets) & $\begin{array}{l}\text { expresses what proportion of total capital is represented by } \\
\text { yet created and currently detained profit of the enterprise }\end{array}$ \\
\hline $\mathrm{Z2}$ & (foreign capital) $\div$ (assets) & $\begin{array}{l}\text { represents the share of foreign capital in the total amount } \\
\text { of corporate capital }\end{array}$ \\
\hline Z3 & (short-term foreign capital) $\div$ assets & $\begin{array}{l}\text { represents the share of short-term foreign capital in the } \\
\text { total amount of corporate capital }\end{array}$ \\
\hline $\mathrm{Z} 4$ & equity $\div$ foreign capital & $\begin{array}{l}\text { represents the share of equity and foreign capital in assets } \\
\text { financing - refers to the degree of coverage of foreign } \\
\text { capital by own resources }\end{array}$ \\
\hline A1 & (assets) $\div$ (revenues) & $\begin{array}{c}\text { how many euros of assets was necessary to achieve one } \\
\text { euro of earnings }\end{array}$ \\
\hline A2 & (current assets) $\div$ (revenues) & $\begin{array}{l}\text { how many euros in operating capital the company used to } \\
\text { achieve revenue of } 1 \text { euro }\end{array}$ \\
\hline
\end{tabular}

Source: Authors' results. 
Table 1 explains more closely the selected ratios in terms of input variables necessary for their quantification and verbal interpretation. Authors have highlighted three key ratios that are crucial indicators of unsuccessful businesses.

According to our specified conditions, an enterprise has been marked unsuccessful, if it simultaneously fulfilled all three criteria:

- Profit after tax gains a negative value (indicator R1 is negative)

- Total liquidity L3 $<1$.

- The ratio of equity to liabilities, i.e. indicator $Z 4<0,04$.

Authors have called these ratios indicators of unsuccessfulness. The market value of an unsuccessful enterprise inevitably decreases, it ceases to be attractive for investors, credit funds are becoming unreachable and additional costs related to the recession are generated.

\subsection{Quantification of selected descriptive statistical characteristics}

For both sets of data (final databases) of years 2014 and 2015, selected descriptive statistical characteristics that define the basic features of the evaluated ratios and allow to determine the model of an unsuccessful etalon company in the market environment of the Slovak Republic (Table 2 and 3) were quantified. The highlighted table columns represent the values of those ratio indicators that serve as a condition of unsuccessfulness of companies.

Table 2

Calculated descriptive statistical characteristics - year 2014

\begin{tabular}{|c|c|c|c|c|c|c|c|c|c|c|c|c|c|}
\hline Characteristic & R1 & $\mathbf{R} 2$ & R3 & $\mathbf{L 1}$ & L2 & L3 & $\mathbf{L} 4$ & $\mathrm{Z1}$ & $\mathrm{Z2}$ & Z3 & $\mathrm{Z4}$ & A1 & A2 \\
\hline Maximum value & 0,000 & 0,867 & 0,000 & 0,991 & 1,000 & 1,000 & 0,000 & 0,943 & 9,988 & 9,977 & 0,040 & 99,707 & 89,191 \\
\hline Minimum value & $-9,786$ & $-9,416$ & $-9,873$ & 0,000 & 0,000 & 0,000 & $-9,814$ & $-9,972$ & 0,962 & 0,007 & $-0,900$ & 0,010 & 0,010 \\
\hline Variation spread & 9,786 & 10,283 & 9,873 & 0,991 & 1,000 & 1,000 & 9,814 & 10,915 & 9,026 & 9,971 & 0,940 & 99,697 & 89,180 \\
\hline Median & $-0,183$ & $-0,153$ & $-0,193$ & 0,056 & 0,249 & 0,400 & $-0,756$ & $-0,255$ & 1,335 & 1,260 & $-0,251$ & 0,858 & 0,421 \\
\hline Average value & $-0,465$ & $-0,416$ & $-0,575$ & 0,126 & 0,328 & 0,441 & $-1,163$ & $-0,868$ & 1,907 & 1,772 & $-0,307$ & 4,039 & 1,625 \\
\hline Lower quartile Q1 & $-0,500$ & $-0,455$ & $-0,544$ & 0,016 & 0,099 & 0,182 & $-1,359$ & $-0,985$ & 1,077 & 1,018 & $-0,517$ & 0,381 & 0,204 \\
\hline Upper quartile Q3 & $-0,057$ & $-0,036$ & $-0,061$ & 0,161 & 0,514 & 0,688 & $-0,312$ & $-0,020$ & 2,069 & 1,946 & $-0,071$ & 2,652 & 0,963 \\
\hline Quartile deviation & 0,222 & 0,210 & 0,241 & 0,073 & 0,208 & 0,253 & 0,523 & 0,483 & 0,496 & 0,464 & 0,223 & 1,136 & 0,379 \\
\hline $\begin{array}{l}\text { Quartile skewness } \\
\text { coefficient }\end{array}$ & $-0,021$ & $-0,019$ & $-0,027$ & 0,002 & 0,012 & 0,009 & $-0,042$ & $-0,120$ & 0,118 & 0,103 & $-0,010$ & 0,747 & 0,062 \\
\hline Standard deviation & 0,834 & 0,785 & 1,096 & 0,171 & 0,271 & 0,292 & 1,402 & 1,515 & 1,442 & 1,434 & 0,266 & 10,064 & 5,560 \\
\hline $\begin{array}{l}\text { Coefficient of } \\
\text { variation }\end{array}$ & $-179,50$ & $-188,62$ & $-190,83$ & 135,541 & 82,527 & 66,230 & $-120,51$ & $-174,41$ & 75,588 & 80,893 & $-86,587$ & 249,178 & 342,115 \\
\hline $\begin{array}{l}\text { Interquartile range } \\
\text { (IRQ) }\end{array}$ & 0,444 & 0,420 & 0,483 & 0,145 & 0,415 & 0,506 & 1,047 & 0,965 & 0,992 & 0,928 & 0,445 & 2,271 & 0,759 \\
\hline $\begin{array}{l}\text { The upper limit for } \\
\text { remote data }\end{array}$ & 0,609 & 0,594 & 0,663 & 0,378 & 1,136 & 1,447 & 1,258 & 1,428 & 3,557 & 3,338 & 0,597 & 6,059 & 2,101 \\
\hline $\begin{array}{l}\text { The lower limit for } \\
\text { remote data }\end{array}$ & $-1,166$ & $-1,085$ & $-1,269$ & $-0,202$ & $-0,524$ & $-0,577$ & $-2,929$ & $-2,432$ & $-0,412$ & $-0,374$ & $-1,185$ & $-3,026$ & $-0,935$ \\
\hline
\end{tabular}

Source: Authors' results.

Etalon unsuccessful enterprise in the national economy of Slovakia in 2014 possessed the average net return on assets $\mathrm{R} 1$ of $(-0.465)$ at the standard deviation of 0,834 . The variability of the values of R1 is considerable, which is confirmed by the value of the coefficient of variation at -179.50 . A similar situation also exists with other Ratios. Total liquidity L3 has an average value of 0.441 with a standard deviation of 0,292. Variability of the indicator L3 in a case of unsuccessful enterprises included in the database is significantly lower compared to the indicator R1. The ratio of equity to foreign capital (Z4) has the average value $(-0.307)$ with a standard deviation of 0.266 . 
Calculated descriptive statistical characteristics - year 2015

\begin{tabular}{|c|c|c|c|c|c|c|c|c|c|c|c|c|c|}
\hline Characteristic & $\mathbf{R} 1$ & $\mathbf{R} 2$ & R3 & L1 & L2 & L3 & L4 & $\mathrm{Z1}$ & $\mathrm{Z2}$ & Z3 & $\mathrm{Z} 4$ & A1 & A2 \\
\hline Maximum value & 0,000 & 4,988 & 0,000 & 0,996 & 1,000 & 1,000 & 0,000 & 0,996 & 9,959 & 9,952 & 0,040 & 99,719 & 98,442 \\
\hline Minimum value & $-9,644$ & $-9,435$ & $-9,894$ & 0,000 & 0,000 & 0,000 & $-9,569$ & $-9,997$ & 0,962 & 0,011 & $-0,900$ & 0,012 & 0,011 \\
\hline Variation spread & 9,644 & 14,423 & 9,894 & 0,996 & 1,000 & 1,000 & 9,569 & 10,992 & 8,997 & 9,941 & 0,940 & 99,707 & 98,431 \\
\hline Median & $-0,173$ & $-0,142$ & $-0,183$ & 0,062 & 0,258 & 0,404 & $-0,746$ & $-0,331$ & 1,361 & 1,270 & $-0,265$ & 0,851 & 0,435 \\
\hline Average value & $-0,443$ & $-0,393$ & $-0,557$ & 0,132 & 0,332 & 0,444 & $-1,190$ & $-0,949$ & 1,958 & 1,812 & $-0,320$ & 3,942 & 1,674 \\
\hline Lower quartile Q1 & $-0,480$ & $-0,429$ & $-0,507$ & 0,016 & 0,106 & 0,190 & $-1,437$ & $-1,149$ & 1,083 & 1,021 & $-0,537$ & 0,385 & 0,211 \\
\hline Upper quartile Q3 & $-0,173$ & $-0,142$ & $-0,183$ & 0,062 & 0,258 & 0,404 & $-0,746$ & $-0,331$ & 1,361 & 1,270 & $-0,265$ & 0,850 & 0,435 \\
\hline Quartile deviation & $-0,052$ & $-0,030$ & $-0,057$ & 0,178 & 0,514 & 0,681 & $-0,305$ & $-0,039$ & 2,158 & 2,036 & $-0,077$ & 2,617 & 1,006 \\
\hline $\begin{array}{l}\text { Quartile skewness } \\
\text { coefficient }\end{array}$ & 0,188 & 0,184 & 0,196 & 0,170 & 0,461 & 0,586 & 0,414 & 0,536 & 1,616 & 1,526 & 0,192 & 2,425 & 0,900 \\
\hline Standard deviation & 0,798 & 0,763 & 1,128 & 0,173 & 0,271 & 0,289 & 1,406 & 1,544 & 1,452 & 1,445 & 0,270 & 9,675 & 5,604 \\
\hline $\begin{array}{l}\text { Coefficient of } \\
\text { variation }\end{array}$ & $-180,15$ & $-194,21$ & $-202,61$ & 131,182 & 81,479 & 65,121 & $-118,12$ & $-162,65$ & 74,180 & 79,746 & $-84,283$ & 245,465 & 334,699 \\
\hline $\begin{array}{l}\text { Interquartile range } \\
\text { (IRQ) }\end{array}$ & 0,307 & 0,287 & 0,324 & 0,046 & 0,152 & 0,213 & 0,691 & 0,817 & 0,278 & 0,250 & 0,271 & 0,466 & 0,224 \\
\hline $\begin{array}{l}\text { The upper limit for } \\
\text { remote data }\end{array}$ & 0,287 & 0,289 & 0,303 & 0,131 & 0,485 & 0,723 & 0,290 & 0,895 & 1,779 & 1,645 & 0,141 & 1,549 & 0,772 \\
\hline $\begin{array}{l}\text { The lower limit for } \\
\text { remote data }\end{array}$ & $-0,939$ & $-0,859$ & $-0,993$ & $-0,052$ & $-0,121$ & $-0,130$ & $-2,472$ & $-2,375$ & 0,666 & 0,646 & $-0,943$ & $-0,314$ & $-0,125$ \\
\hline
\end{tabular}

Source: Authors' results.

In 2015 etalon unsuccessful company in the national economy of Slovakia can be characterized by the average value of net return on assets R1 of $(-0.443)$ and the standard deviation of 0.798 . The coefficient of variation has again a high value in all the ratios. Total liquidity L3 has an average value of 0.444 at the standard deviation of 0.289 . Z4 indicator is represented by the average value of $(-320)$ and the standard deviation of 0.270 .

If indicators of the averatge return $R_{x}$ of the unsuccessful companies are compared year on year, we will find out that $\boldsymbol{R}_{x 2014}<\boldsymbol{R}_{x 2015}$ is true in every case. The same situation occurred in liquidity indicators $L_{x}$. Debt ratios and capital structure indicators $Z_{x}$ had an unfavorable development year on year. It is obvious that in 2015 the unsuccessful enterprises in average improved their values of profitability and liquidity, and on the other hand their level of indebtedness increased.

\subsection{Relationship of the indicators of unsuccessfulness}

Through correlation analysis (Pearson correlation coefficient and coefficient of RSQ determination) pair relationship between indicators of unsuccessfulness (R1, L3, Z4) was inspected.

The corresponding calculations have identified a small, respectively slight pair linear relationship between indicators of unsuccessfulness in years 2014 and 2015 (Table 4).

Table 4

Quantification of correlation coefficient and coefficient of RSQ determination in years 2014 and 2015

\begin{tabular}{|c|c|c|c|c|c|c|c|c|}
\hline Pearson (2014) & R1 & L3 & Z4 & \multirow{8}{*}{ vs. } & Pearson (2015) & R1 & L3 & $\mathrm{Z} 4$ \\
\hline R1 & 1,000 & 0,184 & 0,491 & & R1 & 1,000 & 0,212 & 0,484 \\
\hline L3 & 0,184 & 1,000 & 0,470 & & L3 & 0,212 & 1,000 & 0,506 \\
\hline $\mathrm{Z4}$ & 0,491 & 0,470 & 1,000 & & $\mathrm{Z4}$ & 0,484 & 0,506 & 1,000 \\
\hline RSQ (2014) & R1 & L3 & Z4 & & RSQ (2015) & R1 & L3 & Z4 \\
\hline R1 & 1,000 & 0,034 & 0,241 & & R1 & 1,000 & 0,045 & 0,234 \\
\hline L3 & 0,034 & 1,000 & 0,221 & & L3 & 0,045 & 1,000 & 0,256 \\
\hline $\mathrm{Z4}$ & 0,241 & 0,221 & 1,000 & & $\mathrm{Z4}$ & 0,234 & 0,256 & 1,000 \\
\hline
\end{tabular}

Source: Authors' results. 
It is understandable that unsuccessfulness indicators show a relationship of positive linear relationship, as related financial indicators are used during their construction (for example liabilities consist of, inter alia, foreign capital and it also includes short-term foreign capital) derived from the financial statements. Strong linear correlativity in the indicators of unsuccessfulness would mean that applying only one of the ratio indicators for the assessment of unsuccessfulness of a company would be sufficient. Minimum the linear correlativity was among indicators R1 and L3. The degree of the causal relationship of indicators of unsuccessfulness was evaluated by using a coefficient of RSQ determination. $R S Q$ values reveal the variability and relationship of indicators of unsuccessfulness primarily from other random influences and factors such as mutual pair values of indicators of unsuccessfulness. Therefore it is possible to declare the unsuccessfulness indicators autonomous and useful for assessing the enterprise prosperity.

Unsuccessfulness indicator $L 3$, which has significant informative value in predicting financial failure was investigated in detail. The analysis of liquidity via financial indicators helps to provide early warning of increased risk of financial failure. Thus, it is noted that there are two directions in the analysis of liquidity. The first focuses on the direct relationship between current assets and current liabilities which considers the use of current assets as a main source of meeting current liabilities. This trend contrasts with the continuity of an organization and its profits. Since profitability depends on the use of productive assets, including current assets, disposing of current assets to pay current liabilities prevents the continuity of the organization to continue to perform operations. The second trend based on the main function of financial management of the project which is to estimate the financial needs of the activity, and the provision of necessary sources of funding and investing them to achieve profit and therefore the continuity of the project. To determine the imbalance between these elements leads to financial failure. It should consider the narrow concept of liquidity, which links the direct relationship between current assets and current liabilities (Al-Kasar \& Soileau, 2014). Autors have developed a histogram of corresponding absolute frequencies with 10 classes for both years. The width of the interval of each class is set on 0.0999 for both years. This gives us a slightly left-hand chopped histogram shapes with exponential or logarithmic-normal distribution (Figure 1).
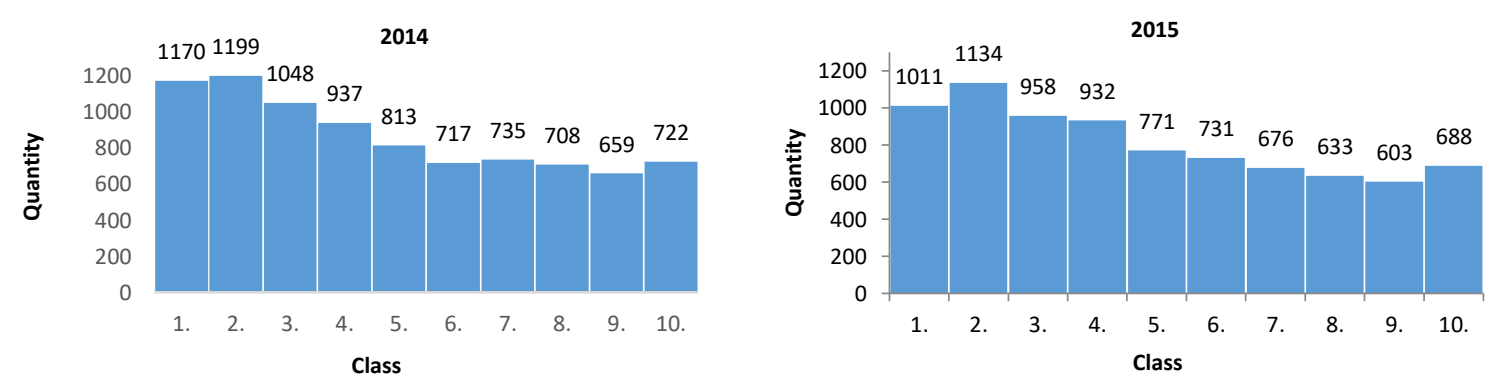

Figure 1. Histogram of absolute quantities of indicator R1 (2014 and 2015) Source: Authors' results.

The closer the value $L 3=1$, the lower the representation of unsuccessful enterprises in particular class. This fact directly confirms the substantial inability of most unsuccessful enterprises to pay its shortterm liabilities. Equally it is possible to observe strong similarity of quantities of individual classes for years 2014 and 2015. 


\subsection{L3 R1, Z4 middle values test}

Through selected test criterion, a test of statistical significance of middle values of indicator L3, R1 and $Z 4$ based on year-on-year comparison was performed.

Authors assumed that the distribution of probability of a random variable L3, R1 and Z4 is not normal, respectively they have no information about the distribution. They have only the assumption about the middle value of the indicator $L 3, R 1$ and $Z 4$ in 2014 expressed by a null hypothesis:

$$
H_{0}: \mu=\mu_{0}
$$

in our case:

L3: $H_{0}: \mu=0,441$ - middle value of $L 3$ indicator of unsuccessful companies in year 2014

R1: $H_{0}: \mu=-0,465$ - middle value of $\mathrm{R} 1$ indicator of unsuccessful companies in year 2014

Z4: $H_{0}: \mu=-0,307$ - middle value of $Z 4$ indicator of unsuccessful companies in year 2014 against an alternative:

$$
\begin{aligned}
& H_{1}: \mu \neq 0,441 \text { (L3) } \\
& H_{1}: \mu \neq-0,465 \text { (R1) } \\
& H_{1}: \mu \neq-0,307 \text { (Z4) }
\end{aligned}
$$

This hypothesis was verified based on the data sample of unsuccessful enterprises against the hypothesis $H_{1}$ with the application of the test criterion:

$$
z=\frac{\bar{x}-\mu_{0}}{\frac{\sigma}{\sqrt{n}}}
$$

where:

$\bar{x}$ - middle value of $L 3, R 1$ and $Z 4$ indicator in year 2015

$\sigma$ - standard deviation of the value of the indicator L3, R1 and Z4 in year 2015

$n$ - sample range in year 2015 (8,137 companies)

The value $\mathrm{z}=0.9364$ for $L 3$, was compared with critical value $-z_{1-\frac{\alpha}{2}}=-z_{0,975}=-1,96 ; z_{1-\frac{\alpha_{2}}{2}}=z_{0,975}=1,96$ based on tabulated values of the distribution function for a normalized normal distribution, thus defining critical area $v_{\alpha}=\left(-\infty,-z_{1-\frac{\alpha}{2}}\right) \cup\left(z_{1-\frac{\alpha}{2}},+\infty\right)$, in our case: $v_{0,05}=(-\infty,-1,96) \cup(1,96,+\infty)$. On the level of significance $\alpha=0,05$, the null hypothesis $H_{0}: \mu=0,441$ was accepted. The difference of the average values of the indicator $L 3$ for unsuccessful companies in years 2014 and 2015 is statistically insignificant based on the selected test criterion. Based on the things stated above, it is possible to conclude that the average value of the indicator L3 relative to unsuccessful companies is in year-on-year period 2014 and 2015 stable and sufficiently representative for its adoption to characterize etalon unsuccessful enterprise.

The value $\mathrm{z}=2.4869$ for $\mathrm{R} 1$ was compared with the same critical value $-z_{0,975}, z_{0,975}$, defining critical area $v_{\alpha}=\left(-\infty,-z_{1-\frac{\alpha}{2}}\right) \cup\left(z_{1-\frac{\alpha}{2}},+\infty\right)$, in our case: $v_{0,05}=(-\infty,-1,96) \cup(1,96,+\infty)$. On level of 
significance $\alpha=0,05$, the null hypothesis $H_{0}: \mu=-0,465$ was rejected. The difference of the average values of the indicator R1 for unsuccessful companies in years 2014 and 2015 is statistically significant based on the selected test criterion. Based on the things stated above, it is possible to conclude that the average value of the indicator R1 relative to unsuccessful companies is in year-on-year period 2014 and 2015 unstable.

The value $z=-4.3432$ for $Z 4$ was compared with the same critical value $-z_{0,975}, z_{0,975}$, defining critical area $v_{\alpha}=\left(-\infty,-z_{1-\frac{\alpha}{2}}\right) \cup\left(z_{1-\frac{\alpha}{2}},+\infty\right)$, in our case: $v_{0,05}=(-\infty,-1,96) \cup(1,96,+\infty)$. On level of significance $\alpha=0,05$, the null hypothesis $H_{0}: \mu=-0,307$ was rejected. The difference of the average values of the indicator Z4 for unsuccessful companies in years 2014 and 2015 is statistically significant based on the selected test criterion. Based on the things stated above, it is possible to conclude that the average value of the indicator Z4 relative to unsuccessful companies is in year-on-year period 2014 and 2015 unstable and unsufficiently representative for its adoption to characterize etalon unsuccessful enterprise.

The inclusion of a particular ratio indicator into the prediction model has a major impact on its predictive power. After analyzing more than 800 bankruptcy models, these can be considered the most common indicators: net income/total assets, current ratio, working capital/total assets, EBIT/total assets, retained earnings/total assets, quick ratio, sales/total assets. There are seven ratios that show they have a direct impact and the most powerful in the calculation of the values of financial performance (Al-Kassar and Soileau, 2012): sales/working capital, sales/accounts receivable, current assets/total liabilities, current assets/current liabilities, current liabilities/total assets, cash/current liabilities, profit before tax/current liabilities. Most represented are predictive models with 5 ratios (models constructed on the principle of discriminant analysis). By the evaluation of the number of used ratio indicators and predictive ability of the model by quantifying the Pearson correlation coefficients, it is possible to conclude that the quality of the model and its explanatory power is not determined by the number of variables involved (for discriminant analysis the value of the Pearson correlation coefficient is -0.06017 and for LOGIT models it is 0.1819 . In many cases, models with lower number of factors are more reliable than models including higher number of factors. Therefore, the model prediction accuracy predominantly depends on the correct selection of variables used.

Models for bankruptcy prediction are constructed on the principle of different methods that allow providing additional information about the behavior of the company and expected development from traditional financial ratios. Their construction is usually based on an assessment of sample of companies that are classified into two categories, i.e. successful and unsuccessful companies. Including an enterprise in the corresponding group may be based on variously defined limit condition, which is determined by a system of selected financial indicators.

Calculation of the analyzed financial ratio indicators will be also executed in further years after acquisition and consequent processing of electronically published financial statements of enterprises. It is necessary to emphasize that due to valid legal regulations, there will be a modification of specified unsuccessfulness conditions ( $Z 4$ indicator). Until 2016, the value was set to $Z 4<0.04$. For 2017, the value increased to $Z 4<0.06$ and for 2018 , to $Z 4<0.08$. Therefore, it is possible to expect the increased number of enterprises meeting the new unsuccessfulness conditions and there will be a more significant change of values of selected descriptive statistic characteristics, which, in turn, will obviously have impact to the definition of etalon unsuccessful enterprise in the national economy of Slovakia. 


\section{CONCLUSION}

In this paper, a universal criterion for inclusion on an enterprise into a category of unsuccessful enterprises through the values of the three ratios (indicators of unsuccessfulness) was defined, while respecting the applicable legal standards governing the conditions of unsuccessfulness in Slovak Republic. Then authors defined the average unsuccessful business in the current market environment of the Slovak Republic through selected ratio indicators. The average values of indicators of unsuccessfulness have characterized so called etalon unsuccessful enterprise, which serves as the standard comparative basis for other unsuccessful companies. Authors realize that the industry, geographical coverage, scope of business, size of business, and other determinants may have a significant impact on the values of quantified ratios. That is why the further research that will be carried out on a level of selected sectors of the national economy and will mutually compare the identified differences between them and the average unsuccessful enterprise is planning. Our research will continue in the next years by the accumulation of financial statements of the enterprises and the subsequent quantification of descriptive statistical characteristics of the unsuccessful enterprises database in the Slovak Republic.

\section{ACKNOWLEDGEMENT}

This research was financially supported by the Slovak Research and Development Agency - Grant NO. APVV-14-0841: Comprehensive Prediction Model of the Financial Health of Slovak Companies.

\section{REFERENCES}

Al-Kassar, T. A., \& Soileau, J. S. (2014). Financial performance evaluation and bankruptcy prediction (failure) 1. Arab Economic and Business Journal, 9(2), 147-155.

Al-Kassar, T., \& Soileau, J. (2012). Design and Applied Mathematical Model of Measuring Financial Performance Evaluation: Jordan Results. Oil, Gas \& Energy Quarterly, 60(3), 621-636.

Balcaen, S., \& Ooghe, H. (2006). 35 years of studies on business failure: an overview of the classic statistical methodologies and their related problems. The British Accounting Review, 38(1), 63-93.

Balcerzak, A. P., Kliestik, T., Streimikiene, D., \& Smrčka, L. (2017). Non-parametric approach to measuring the efficiency of banking sectors in European Union Countries. Acta Polytechnica Hungarica, 14(7), 51-70.

Bemmann, M. (2005). Improving the Comparability of Insolvency Predictions. Dresden Discussion Paper in Economics, 8 , 148.

Cinca, C. S., Molinero, C. M., \& Larraz, J. G. (2005). Country and size effects in financial ratios: A European perspective. Global Finance Journal, 16(1), 26-47.

Delen, D., Kuzey, C., \& Uyar, A. (2013). Measuring firm performance using financial ratios: A decision tree approach. Expert Systems with Applications, 40(10), 3970-3983.

Dobrovic, J., Lambovska, M., Gallo, P., \& Timkova, V. (2018). Non-financial indicators and their importance in small and medium-sized enterprises. JOURNAL OF COMPETITIVENESS, 10(2), 41-55.

Gavurova, B., Belas, J., Kocisova, K., \& Kliestik, T. (2017). Comparison of selected methods for performance evaluation of Czech and Slovak commercial banks. Journal of Business Economics and Management, 18(5), 852-876.

Horrigan, J. O. (1965). Some empirical bases of financial ratio analysis. The Accounting Review, 40(3), 558-568.

Janoskova, K., \& Kliestikova, J. (2018). Analysis of the Impact of Selected Determinants on Brand Value. Journal of International Studies, 11(1), 152-162.

Kliestik, T., Misankova, M., Valaskova, K. \& Svabova, L. (2018) Bankruptcy prevention: new effort to reflect on legal and social changes. Science and Engineering Ethics, 24(2), 791-803.

Kumar, P. R., \& Ravi, V. (2007). Bankruptcy prediction in banks and firms via statistical and intelligent techniques-A review. European journal of operational research, 180(1), 1-28.

Lando, D. (2004). Credit risk modeling: Theory and Application. New Jersey: Princeton University Press. 
Liang, D., Lu, C. C., Tsai, C. F., \& Shih, G. A. (2016). Financial ratios and corporate governance indicators in bankruptcy prediction: A comprehensive study. European Journal of Operational Research, 252(2), 561-572.

Liang, Q., Xu, P., \& Jiraporn, P. (2013). Board characteristics and Chinese bank performance. Journal of Banking \& Finance, 37(8), 2953-2968.

Libby, R. (1975). Accounting ratios and the prediction of failure: Some behavioral evidence. Journal of Accounting Research, 150-161.

Maricica, M., \& Georgeta, V. (2012). Business failure risk analysis using financial ratios. Procedia - Social and Behavioral Sciences, 62, 728-732.

Mears, P. (1966). Financial Ratios As Predictors Of Failure-Discussion. Journal of Accounting Research, 4, 119-122.

Mihalovic, M. (2016). Performance comparison of multiple discriminant analysis and logit models in bankruptcy prediction. Economics \& Sociology, 9(4), 101-118. doi: 10.14254/2071-789X.2016/9-4/6

Mousavi, M. M., Ouenniche, J., \& Xu, B. (2015). Performance evaluation of bankruptcy prediction models: An orientation-free super-efficiency DEA-based framework. International Review of Financial Analysis, 42, 64-75.

Rowland, Z., Dvorakova, L. \& Pousek, P. (2016). Stanovení bankrotního modelu dopravních podnikú v CR pomoci vicenasobne diskriminacni analyzy. Ekonomicko-manazerske spektrum, 1, 2-11.

Svabova, L., \& Durica, M. (2016). Korelačná analýza prediktorov použitých v bankrotných predikčných modeloch na Slovensku. Ekonomicko manazerske spektrum, 10(1), 2-11. 